FACTA UNIVERSITATIS

Series: Physical Education and Sport, Vol. 18, No 2, 2020, pp. 409 - 416

https://doi.org/10.22190/FUPES200909038M

Research article

\title{
THE RELATIONSHIP BETWEEN PLAYING SPORTS AND SELF-EFFICACY IN PEOPLE WITH DISABILITIES
}

UDC 615.01-056.24

\section{Petar Mitić, Bojan Jorgić, Ivan Popović, Miljan Hadžović}

Faculty of Sport and Physical Education, University of Niš, Niš, Serbia

\begin{abstract}
Self-efficacy is an assessment of an individual's own ability to organize and perform certain actions necessary to achieve the desired outcomes, and its development is very important. The research aimed to determine whether participation in sports and success in playing sports are associated with more pronounced self-efficacy in people with disabilities, and included two studies. The aim of the first study was to examine the differences in self-efficacy between those who play sports (goalball) and those who do not play sports on a sample of people with visual impairment, as well as whether this difference exists between goalball players of different levels of performance. The aim of the second study was to examine the existence of differences in self-efficacy between wheelchair basketball players and non-wheelchair basketball players. The Generalized Self-Efficacy Scale consisting of ten statements was used as the measuring instrument and the respondents stated how much each item refers to them on a five-point Likert-type scale (from 0 to 4). In data processing the statistical method of the t-test, univariate analysis of variance (One way ANOVA), as well as the Post-Hoc test, were used. The results show that people with disabilities who play sports have more pronounced self-efficacy compared to those who do not play sports, as well as compared to athletes without disabilities. Statistical differences in self-efficacy between athletes with disabilities of different levels of performance have not been identified.
\end{abstract}

Key words: Self-Efficacy, Goalball, Wheelchair Basketball

Received September 09, 2020 / September 16, 2020

Corresponding author: Petar Mitić

Faculty of Sport and Physical Education, University of Niš, Čarnojevića 10a, Niš, Serbia

Phone: + 38118510900 •E-mail: mitic.petar@gmail.com 


\section{INTRODUCTION}

Self-efficacy represents a self-evaluative construct and it is one of the basic terms of the Social Cognitive Theory (SCT) of Albert Bandura. Bandura (1995) defines self-efficacy as an assessment of an individual's own ability to organize and perform certain actions necessary to achieve the desired outcomes. It reflects how confident a person is that he or she possesses the personal capacities that allow him or her to fully control the outcomes of set goals, despite disruptive events, difficulties, and obstacles (Bandura, 1986). If a person has manifested a higher estimation of their self-efficacy, she or he will be encouraged to act in accordance with their goals. Individuals with a strong belief in their self-efficacy are likely to set high goals for themselves, effectively control their work and commitment, will be persistent in their attempts to achieve satisfactory success, i.e. to achieve the set goal (Genc, Pekić, \& Matanov, 2013). Self-efficacy is, according to Bandura (1995), mostly situation-specific, but research shows the existence of general self-efficacy (Lindley \& Borgen, 2002).

Self-efficacy is not a genetically determined trait, but is an evolving characteristic (Maddux \& Gosselin, 2012). Smederevac and Mitrović (2009) summarize four main sources of self-efficacy: 1) the "power of experience" as the most influential source, emphasizing that if a person has only easy successes or failures, he will not gain resilient self-efficacy, for which it is necessary to have experience in the form of overcoming problems through effort; 2) model learning is another source of self-efficacy; 3) the third source of self-efficacy is "social pressure", i.e. reassurance by others that a person can succeed in a particular activity; 4) interpretation of physical and emotional states (anxiety, tension, depression, fatigue) can contribute to the expression of self-efficacy.

Higher levels of self-efficacy have a positive effect on many psychological aspects (Maddux \& Gosselin, 2012). Generalized self-efficacy facilitates coping with stress, but also affects the cognitive assessment of a stressful situation (Jerusalem \& Schwarzer, 1992), i.e. it is an important factor that can moderate the impact and interpretation of the relationship between personality traits and perceived stress (Ebstrup, Eplov, Pisinger, \& Jørgensen, 2011).

Research done on the sports population in the broadest sense shows a positive relationship between perceived self-efficacy and performance in many sports (through effort and perseverance in sports activities as a moderator of the variable) (Mueller, 1992; Weigand \& Stockham, 2000). In addition to being motivating, a high assessment of one's effectiveness helps reduce the fear of injury and thus affects the success in acquiring new motor skills (Perkos, Theodorakis, \& Chroni, 2002). People who have a higher selfassessment of their abilities (self-efficacy) achieve better results in mastering the more complex elements of skiing technique (Cigrovski, Matković, \& Ivanec, 2008). A high level of perceived self-efficacy reduces the chances of the athlete applying self-handicapping strategies, i.e., looking in advance for reasons for poor performance, and coaches are encouraged to work on improving self-efficacy (Kuczka \& Treasure, 2005).

Practicing sports can, in addition to physical and health benefits, also contribute to mental well-being (Moss, Landon, \& Fleming, 2017). People with visual impairments who do sports are better socialized than those who do not do sports (Movahedi, Mojtahedi, \& Farazyani, 2011) and they have a more adequate self-concept (Koolaee, 2017). Selfefficacy is a very important factor for the decision of persons with disabilities to engage in sports (Dixon-Ibarra \& Driver, 2013), and on the other hand, it is assumed that participation 
in sports will increase the self-efficacy of persons with disabilities (Moss et al., 2017). Also, the self-efficacy of teachers in working with students with disabilities is extremely important (Block, Taliaferro, Harris \& Krause, 2010) and increases with participation in specialized programs (Tindall, Culhane, \& Foley, 2016; Reina, Santana, Montesdeoca, \& Roldan, 2019; Foley, Santarossa, Tindall, \& Lieberman, 2020).

Many sports are primarily intended for people with disabilities. Goalball, designed in 1946 by Hanz Lorenzen and Sepp Reindletog (Jorgić, Grbović, Đorđević, Stanković, \& Stanković, 2019 ) is considered the "identity card" of blind and partially sighted people. It is designed to be a part of the rehabilitation of veterans with a visual impairment from the Second World War (Aleksandrović, Jorgić, \& Mirić 2016). Currently, the most successful countries in goalball are Lithuania, USA, Brazil, Turkey, Denmark, Sweden, Finland, Canada, Spain, China, Iran, etc. (Milenković, Milenković, \& Cvetković, 2014). One team includes three players, and the goal is to throw the ball, which contains bells, into the opponent's net.

Players throw the ball on the ground from one end of the field to the other, and the players remain in the selected area during both the attack and defense. Players must use the ringing tone to estimate the position and movement of the ball. The game itself consists of two halves of twelve minutes each. Blindfolded and visually impaired competitors wear blindfolds so that the conditions of the game itself are equal for all the players and visually impaired competitors would not have an advantage (Madić, Stanojević, Aleksandrović, \& Jorgić, 2015). Wheelchair basketball is very popular and the most developed team competitive sport for people with disabilities (Molik et al., 2009). In wheelchair basketball male players, self-efficacy is associated with adequate goal scoring (Katartzi, Theodorakis, Tzetzis, \& Vlachopoulos, 2007), while the development of self-efficacy in wheelchair basketball female players is associated with the severity of disability (Schliermann \& Stoll, 2007).

In this paper, we deal with the issue of general self-efficacy in athletes with disabilities in order to determine whether participation in sports and success in sports are associated with more pronounced self-efficacy. With this intention, we conducted two studies. The first study aims is to examine the differences in self-efficacy between those who play sports (goalball) and those who do not play sports, on a sample of people with visual impairment. An additional goal is to examine whether this difference exists between goalball players of different levels of success. The second study aims to examine differences in self-efficacy between wheelchair basketball players and non-wheelchair basketball players.

\section{METHODS}

\section{Sample}

The sample in Study 1 consisted of 52 males with visual impairment. The participants were from Serbia, Montenegro, Bosnia and Herzegovina, Hungary, Romania, and Macedonia. Based on the level of competition, the participants were divided into three groups: an international level-c group (19 participants), national level-European group (17 participants), and a subsample of non-athletes (16 participants). The criterion for inclusion in the first subgroup was participation in international competitions and more than three training sessions per week. Based on sports status, the participants were divided into two groups: athletes (36) and non-athletes (16). The sample in Study 2 consisted of 22 wheelchair basketball players and 14 non-disabled basketball players. 


\section{Instrument}

The Generalized Self-Efficacy Scale was used as the measuring instrument (Jerusalem $\&$ Schwarzer, 1992). It consists of ten statements, and the participants state how much each item refers to them on a five-point Likert-type scale (from 0 to 4 ). The score is onedimensional and is obtained by simply adding marked answers to all questions. A higher score indicates a higher level of self-efficacy. One of the main reasons for using this scale (among many others that examine self-efficacy) is the existence and availability of verified versions in the Romanian, Hungarian and Macedonian language, in addition to Serbian. This is very important because the participants come from different language areas. Also, in previous research, this scale has shown solid results when it comes to reliability (Schwarzer, Basler, Kwiatek, Schroder, \& Zhang, 1997; Ivanov, 2002).

\section{Statistical Analysis}

In data processing, the statistical methods of the t-test, univariate analysis of variance (One way ANOVA), as well as the Post-Hoc test were used.

\section{RESULTS}

The results presented in Table 1 show that the differences in the level of self-efficacy between visually impaired people who practice goalball and those who do not practice sports are statistically significant at the level of 0.00 .

Table 1 Differences in self-efficacy between athletes and non-athletes with visual impairment

\begin{tabular}{llccccc}
\hline Variable & & T & Df & Sig. (2-tailed) & $\begin{array}{c}\text { Mean } \\
\text { Difference }\end{array}$ & $\begin{array}{c}\text { Std. Error } \\
\text { Difference }\end{array}$ \\
\hline \multirow{2}{*}{ Self-efficacy } & Equal variances assumed & 6.038 & 50 & 0.000 & 4.205 & 0.696 \\
& Equal variances not assumed & 5.718 & 27.766 & 0.000 & 4.205 & 0.735 \\
\hline
\end{tabular}

It was assumed that there were statistically significant differences between goalball players at the international and national level, between goalball players playing at an international level and non-athletes, and between goalball players at a national level, and nonathletes in terms of self-efficacy. Internationally ranked goalball players were expected to have the most pronounced self-efficacy, followed by those nationally ranked, and the least pronounced self-efficacy was expected for non-athletes. To test these hypotheses, an ANOVA was calculated, and the results are shown in Table 2. The presented parameters indicate the existence of differences between the selected subgroups of the examined sample.

Table 2 Differences between athletes with visual impairment of different ranks and nonathletes with visual impairment - the ANOVA method

\begin{tabular}{lcrccc}
\hline Self-efficacy & Sum of Squares & Df & Mean Square & F & Sig. \\
\hline Between Groups & 229.835 & 2 & 114.917 & 22.530 & 0.000 \\
Within Groups & 249.934 & 49 & 5.101 & & \\
\hline Total & 479.769 & 51 & & & \\
\hline
\end{tabular}


In order to see exactly which subgroups these statistically significant differences exist between, a Post-hoc test was calculated. The results are shown in Table 3 and they indicate that there is a statistically significant difference between international level goalball players and non-athletes, as well as between national level goalball players and non-athletes at a significance level of 0.00 , while the difference between national and international level goalball players is not statistically significant.

Table 3 Results of the Post-hoc test to determine the differences between athletes with visual impairment of different ranks and non-athletes with visual impairment

\begin{tabular}{llccc}
\hline (I) Level of competition & & $\begin{array}{c}\text { Mean } \\
\text { Difference } \\
(\mathrm{I}-\mathrm{J})\end{array}$ & $\begin{array}{c}\text { Std. } \\
\text { Error }\end{array}$ & Sig. \\
\hline \multirow{2}{*}{ International } & National & 1.780 & 0.766 & 0.073 \\
& Non-athletes & $5.019^{*}$ & 0.754 & 0.000 \\
\hline \multirow{2}{*}{ National } & International & -1.780 & 0.766 & 0.073 \\
& Non-athletes & $3.239^{*}$ & 0.787 & 0.000 \\
\hline \multirow{2}{*}{ Non-athletes } & International & $-5.019^{*}$ & 0.754 & 0.000 \\
& Non-athletes & $-3.239^{*}$ & 0.787 & 0.000 \\
\hline
\end{tabular}

Study 2 aimed to compare the expression of self-efficacy in basketball players with and without disabilities. Even from the parameters of descriptive statistics (Table 4), a clear difference in the expression of self-efficacy can be seen between basketball players with and without disabilities, with wheelchair basketball players achieving higher scores on the self-efficacy scale. Using the t-test, these differences were also shown to be statistically significant (Table 5).

Table 4 The expression of self-efficacy in basketball players with and without disabilities

\begin{tabular}{llcccc}
\hline Variable & Sport & N & Mean & $\begin{array}{c}\text { Std. } \\
\text { Deviation }\end{array}$ & $\begin{array}{c}\text { Std. } \\
\text { Error Mean }\end{array}$ \\
\hline \multirow{2}{*}{ Self-efficacy } & Wheelchair basketball players & 22 & 32.7727 & 5.73155 & 1.22197 \\
& Basketball players & 14 & 26.1429 & 4.95917 & 1.32539 \\
\hline
\end{tabular}

Table 5 Differences in self-efficacy between basketball players with and without disabilities

\begin{tabular}{lccccc}
\hline Variable & F & Sig. & T & df & Sig. (2-tailed) \\
\hline Self-efficacy & 0.231 & 0.634 & 3.559 & 34 & 0.001 \\
\hline
\end{tabular}

\section{DISCUSSION}

The results obtained in this research clearly show that participation in sports is associated with more pronounced self-efficacy in people with disabilities. The results indicate that differences in the level of self-efficacy between visually impaired people who engage in goalball and those who do not engage in sports are statistically significant. Practically, this data tells us that those with visual impairments who practice goalball believe more in their own resources compared to people with visual impairments who do 
not play sports. This is proof that playing sports is extremely important for visually impaired people, for the mental, and not only physical (which is somewhat taken for granted) aspects of health and life satisfaction. The results in this segment, which indicate the existence of statistically significant differences between internationally ranked athletes and non-athletes, as well as between nationally ranked athletes and non-athletes, with no statistically significant differences between internationally and nationally ranked athletes, indicate another important fact regarding the development of self-efficacy and playing sports among the blind and visually impaired - it does not matter how successful you are in goalball, it is important that you play it. Particularly interesting is the data obtained in the second part of the research, which refers to the fact that the self-efficacy of wheelchair basketball players is drastically higher compared to basketball players who are without disabilities. It should be taken into account that the more pronounced self-efficacy of persons with disabilities is a significant factor in opting for sports (Dixon-Ibarra \& Driver, 2013), and it can be considered that persons with disabilities who are active have already had more pronounced self-efficacy than those who did not engage in organized sports activities. However, the results obtained are in agreement with the claims that participation in sports leads to increased self-efficacy (Moss et al., 2017).

Such a high level of self-efficacy in people with disabilities, especially those who play sports, can be explained if we keep in mind the main sources of self-efficacy. These sources are experience, model learning, persuasion and interpretation of physical and emotional states (Smederevac \& Mitrović, 2009). "The power of experience" as the most influential source says that if a person has only easy successes or failures, he will not gain resilient self-efficacy, for which it is necessary to have experience in the form of overcoming problems through effort. It is common sense to assume that people with disabilities have achieved their success by making greater efforts than people without physical disabilities. The reduction of mental and physical tension that only physical activity brings can also affect the more favorable perception of one's own abilities.

Whatever the mechanisms underlying increasing the self-efficacy of people with disabilities through organized sports activities are, the most important thing is the outcome. People who have more pronounced faith in their own abilities will set high goals, effectively control their work and commitment, and will be persistent in their attempts to achieve satisfactory success (Genc et al., 2013). This belief in the possession of personal capacities and work on achieving high and realistic goals, despite the difficulties and obstacles, is necessary for every individual, especially for people with disabilities. The participants in this study are people with physical disabilities, and sport is an activity that is primarily based on physical activity. Therefore, playing sports for these people is perhaps the most effective way of full integration and a way to overcome life's obstacles. People with physical disabilities overcome the barrier that determines their disability by playing sports.

\section{CONCLUSION}

The development of self-efficacy is extremely important because people who have more pronounced self-efficacy will set higher goals and work on achieving them despite the obstacles. It is very important for people with physical disabilities to build resilient selfefficacy. The results of the research strongly suggest that participation in organized sports activities is an excellent way to strengthen self-efficacy for people with disabilities, 
although it is not related to success in the sport itself. The limitation of this study lies, above all, in the relatively small sample, but it provides a basis for further research into the psychological benefits that can result from engaging in sports for people with disabilities.

\section{REFERENCES}

Aleksandrović, M., Jorgić, B., \& Mirić, F. (2016). Holistički pristup adaptivnom fizičkom vežbanju-udžbenik za studije master akademskih studija (A holistic approach to adaptive physical exercise-a textbook for master's academic studies). Niš: Faculty of Sport and Physical Education, University of Niš. In Serbian

Bandura A. (1995). Exercise of personal and collective efficacy in changing societies. In: A. Bandura (Ed.). Selfefficacy in changing societies. UK: Cambridge University Press.

Bandura, A. (1986). The explanatory and predictive scope of self-efficacy theory. Journal of Social and Clinical Psychology, 4(3), 359-373.

Block, M., Taliaferro, A., Harris, N., \& Krause, J. (2010). Using self-efficacy theory to facilitate inclusion in general physical education. Journal of Physical Education, Recreation \& Dance, 81(3), 43-46.

Cigrovski, V., Matković, B., \& Ivanec, D. (2008). Uloga psiholoških čimbenika u procesu stjecanja skijaških znanja. Hrvatski športskomedicinski vjesnik, 23(1), 45-50.

Dixon-Ibarra, A., \& Driver, S. (2013). The role of self-efficacy in physical activity for person with disabilities. Palaestra, 27(4).

Ebstrup, J.F., Eplov, L.F., Pisinger, C., \& Jørgensen, T. (2011). Association between the Five Factor personality traits and perceived stress: is the effect mediated by general self-efficacy?. Anxiety, Stress and Coping, 24(4), 407-419.

Foley, J.T., Santarossa, S., Tindall, D.W., \& Lieberman, L.J. (2020). The Impact of a summer sports camp for children with visual impairments on the self-efficacy of physical education pre-service teachers: A pilot study. European Journal of Adapted Physical Activity, 13(3), doi: 10.5507/euj.2019.011

Genc, A., Pekić, J., \& Matanov, J. (2013). Mehanizmi suočavanja sa stresom, optimizam i generalna samoefikasnost kao prediktori psihofizičkog zdravlja (Mechanisms of coping with stress, optimism and general self-efficacy as predictors of psychophysical health). Primenjena psihologija, 6(2), 155-174. In Serbian

Ivanov, L. (2002). Skala opće samoefikasnosti (General self-efficacy scale). In: K. Lacković-Grgin \& Z. Penezic (Eds.), Zbirka psihologijskih mjernih instrumenata (Collection of psychological measuring instruments). Zadar: Faculty of Philosophy in Zadar, Croatia. In Croatian

Jerusalem, M., \& Schwarzer, R. (1992). Self-efficacy as a resource factor in stress appraisal processes. In: R. Schwarzer, (Ed.). Self-efficacy: Thought control of action, (pp.195-213). Washington, DC, US: Hemisphere Publishing Corporation.

Jorgić, B., Grbović, A., Đorđević, S., Stanković, V., \& Stanković, R. (2019). Influence of certain motor abilities on ball throwing velocity in goalball: a pilot study. Facta Universitatis Series Physical Education and Sport, 17(2), 195-203.

Katartzi, E., Theodorakis, Y., Tzetzis, G., \& Vlachopoulos, S.P. (2007). Effects of goal setting and self-efficacy on wheelchair basketball performance. Japanese Journal of Adapted Sport Science, 5(1), 50-62.

Koolaee, A.K. (2017). Sport as an effective goal to increase self-concept and hope: a comparison study between athlete and non-athlete women with visual impairments. Social Determinants of Health, 3(2), 98-103.

Kuczka, K.K., \& Treasure, D.C. (2005). Self-handicapping in competitive sport: Influence of the motivational climate, self-efficacy, and perceived importance. Psychology of Sport and Exercise, 6(5), 539-550.

Lindley, L.D., \& Borgen, F.H. (2002). Generalized self-efficacy, Holland theme self-efficacy, and academic performance. Journal of Career Assessment, 10(3), 301-314.

Maddux, J.E., \& Gosselin, J.T. (2012). Self-efficacy. The Guilford Press.

Madić, D., Stanojević, I., Aleksandrović, M., \& Jorgić, B. (2015). Goalball-Sport for people with visual impairments. In D. Rajić (Ed.). Book of Proceedings of the 8th International Interdisciplinary Scientific Technical Conference Horizons, (pp. 150-155). Subotica: College of Vocational Studies for the Education of Preschool Teachers and Sports Trainers.

Milenković, D., Milenković, V., \& Cvetković, S. (2014). Serbian/Yugoslav athletes participation at Paralympic Games. Materiales para la Historia del Deporte, 12, 52-62.

Molik, B., Kosmol, A., Morgulec'Adamowicz, N., Laskin, J.J., Jezior, T., \& Patrzałek, M. (2009). Game efficiency of elite female wheelchair basketball players during world championships (Gold Cup) 2006. European Journal of Adapted Physical Activity, 2(2), 26-38

Moss, T., Landon, T.J., \& Fleming, A. (2017). Sports and disability: Enhanced health, self-efficacy, and social inclusion through athletic participation. Review of Disability Studies: An International Journal, 13(3), 1-19 
Movahedi, A., Mojtahedi, H., \& Farazyani, F. (2011). Differences in socialization between visually impaired student-athletes and non-athletes. Research in Developmental Disabilities, 32(1), 58-62.

Mueller, L.M. (1992). The effect of general and task-specific self-efficacy on the performance of a fine motor task. Journal of Sport Behavior, 15(2), 130-140.

Perkos, S., Theodorakis, Y., \& Chroni, Y. (2002). Enhancing performance and skill acquisition in novice basketball players with instructional self-talk. The Sport Psychologist, 16(4), 368-383.

Reina, R., Santana, A., Montesdeoca, R., \& Roldan, A. (2019). Improving self-efficacy towards inclusion in inservice physical education teachers: a comparison between Insular and Peninsular regions in Spain. Sustainability, 11(20), 5824. https://doi.org/10.3390/su11205824

Schliermann, R., \& Stoll, O. (2007). Self-efficacy and sport-anxiety of German elite female wheelchair basketball players. Sobama Journal, 12(1), 135-139.

Schwarzer, R., Basler, J., Kwiatek, P., Schroder, K., \& Zhang, J.X. (1997). The assessment of optimistic selfbeliefs: Comparison of the German, Spanish and Chinese version of the general self-efficacy scale. Applied Psychology: An International Review, 46(1), 69-88.

Smederevac, S., \& Mitrović, D. (2009). Ličnost-metode i modeli (Personality-methods and models). Belgrade: Center for Applied Psychology. In Serbian

Tindall, D.W., Culhane, M., \& Foley, J.T. (2016). Pre-service teachers' self-efficacy towards children with disabilities: An Irish perspective. European Journal of Adapted Physical Activity, 9(1), 27-39.

Weigand, D.A., \& Stockham, K.J. (2000). The importance of analyzing position-specific self-efficacy. Journal of Sport Behavior, 23(1), 61-69.

\section{ODNOS BAVLJENJA SPORTOM I SAMOEFIKASNOSTI OSOBA SA INVALIDITETOM}

Samoefikasnost, čiji je razvoj izuzetno značajan, predstavlja procenu sopstvenih sposobnosti organizovanja i preduzimanja određenih radnji koje su neophodne za postizanje željenih ishoda. Da bi se utvrdilo da li su bavljenje sportom i uspeh u sportu povezani sa izraženijom samoefikasnošću kod osoba sa invaliditetom, sprovedene su dve studije. Cilj prve studije, koja je izvedena na uzorku osoba sa oštećenjem vida, bio je da ispita razlike u izraženosti samoefikasnosti između onih koji se bave sportom (golbalom) $i$ onih koji se ne bave sportom, kao i da utvrdi da li postoji razlika između golbalista različitih nivoa uspešnosti. Cilj druge studije bio je da ispita postojanje razlika u samoefikasnosti između košarkaša u kolicima i košarkaša bez invaliditeta. Kao merni instrument korišćena je Generalizovana Skala Samoefikasnosti koja sačinjena od deset tvrdnji. Ispitanici su putem petostepene skale Likertovog tipa (od 0 do 4), odgovarali na svaku od stavki. U obradi podataka korišćena su statističke metode t-test, univarijantna analiza varijanse (One way ANOVA), kao i Post-Hoc test. Rezultati pokazuju da osobe sa invaliditetom koje se bave sportom imaju izraženiju samoefikasnost u odnosu ne samo na osobe sa invaliditetom koje se ne bave sportom, već i u odnosu na sportiste bez invaliditeta. Statističke razlike u samoefikasnosti među sportistima sa invaliditetom različitih nivoa uspešnosti nisu identifikovane.

Ključne reči: samoefikasnost, golbal, košarka u kolicima 